\title{
Integrating Kaolin Clay for Ambrosia Beetle Management in Ornamental Crops of Eastern Redbud
}

\author{
Christopher T. Werle ${ }^{1}$ \\ Thad Cochran Southern Horticultural Laboratory, USDA-ARS, 810 Highway \\ $26 \mathrm{~W}$, Poplarville, MS 39470
}

Karla M. Addesso

Otis L. Floyd Nursery Research Center, College of Agriculture, Human and Natural Sciences, Tennessee State University, 472 Cadillac Lane, McMinnville, TN 37110

Blair J. Sampson
Thad Cochran Southern Horticultural Laboratory, USDA-ARS, 810 Highway
$26 \mathrm{~W}$, Poplarville, MS 39470

Jason B. Oliver

Otis L. Floyd Nursery Research Center, College of Agriculture, Human and Natural Sciences, Tennessee State University, 472 Cadillac Lane, McMinnville, TN 37110

John J. Adamczyk

Thad Cochran Southern Horticultural Laboratory, USDA-ARS, 810 Highway, 26 W, Poplarville, MS 39470

Additional index words. Cercis canadensis, eastern redbud, IPM, Xyleborina, bifenthrin, particle film

\begin{abstract}
Invasive ambrosia beetles (Coleoptera: Curculionidae) are an important pest problem at ornamental tree nurseries. Available chemical treatments are not completely effective and, due to the length of the beetle dispersal period and insecticide breakdown, repeated treatments can become costly in terms of application expense and nontarget impacts. Additional options are needed to reduce application frequency and to provide an acceptable level of crop protection. Four treatments were tested using ethanolinjected eastern redbud trees at research sites in Mississippi (MS) and Tennessee (TN) over 2 years (2014-15), with the number of new ambrosia beetle galleries compared over time on 1) nontreated control trees, 2) kaolin-treated trees, 3) bifenthrin-treated trees, and 4) kaolin + bifenthrin $(k+b)$-treated trees. Kaolin-treated trees rapidly lost their coating after rain events and, at 6 days after treatment (DAT) in TN, no differences were detected in the number of beetle galleries between kaolin and nontreated control trees. Kaolin + bifenthrin-treated trees appeared to retain treatment residue longer, but were not better-protected than bifenthrin-treated trees at any time. Further research is needed to determine whether an adjuvant, such as a surfactant, spreader, or sticker, may enhance the modest impact offered by kaolin in our test, or if a reduction in rates of bifenthrin may be allowable.
\end{abstract}

Invasive ambrosia beetles (Curculionidae: Scolytinae) have been challenging to profitable nursery production of ornamental trees in the southeastern United States for decades (Mizell et al., 1994; Oliver and Mannion, 2001). Foundress females disperse from peripheral forest habitats into nurseries, tunnel into susceptible trees, and inoculate their brood gallery with symbiotic fungi that is consumed by larvae and adults alike (Biedermann and Taborsky, 2011; Reding

Received for publication 9 Sept. 2016. Accepted for publication 4 Nov. 2016.

${ }^{1}$ Corresponding author. E-mail: chris.werle@ars. usda.gov. production in the southeastern United States (Fulcher et al., 2012; Werle et al., 2015).

A better understanding of timing and distance of dispersal flights are contributing to a more efficient monitoring program for ambrosia beetles, enabling growers to time preventative treatments for maximum efficacy (Ranger et al., 2015; Reding et al., 2011; Werle et al., 2015). Despite pesticide use, susceptible trees may remain vulnerable to ambrosia beetle attack. Repeated applications of insecticide are necessary for maintaining protection on a nursery tree crop due to the long ambrosia beetle flight period (Hudson and Mizell, 1999; Werle et al., 2015). Multiple treatments can be costly for the grower and can impact natural enemies of a variety of arthropod pests, leading to secondary pest outbreaks that reduce plant vigor and decrease marketability of a crop (Frank and Sadoff, 2011). In addition, registrations of some classes of insecticides currently are being reviewed by environmental protection organizations, and may be rescinded due to nontarget impacts on pollinating insects (Campbell, 2013). Therefore, effective alternatives are needed to improve the efficacy of conventional insecticides and prevent the development of resistance and emergence of secondary pests (Pimentel et al., 1992). Development of a comprehensive push-pull integrated pest management (IPM) strategy may be a cost-effective approach for managing destructive ambrosia beetles (Cook et al., 2007). This strategy incorporates visual and olfactory cues as well as optimal trap design and crop location, which may deter beetles from attacking trees (push) while drawing them into lethal traps (pull) (Burbano et al., 2012; Cook et al., 2007; Ranger et al., 2011, 2012, 2013; Reding et al., 2015; VanDerLaan and Ginzel, 2013; Werle et al., 2015).

Use of particle films such as kaolin clay has become selectively integrated into crop protection programs (Glenn et al., 1999). Typically used in tree fruit protection, kaolin applications coat foliage, trunk, and fruit alike, disrupting reproduction of existing pest populations or deterring immigrating pests. Treated trees become unrecognizable to pests due to the white reflective surface. While this approach has successfully targeted aphids, lace bugs, fruit flies, thrips, psyllids, whiteflies, and leafhoppers, there is potential for wider pest management applications for kaolin (Glenn et al., 1999; Marcotegui et al., 2015; Mazor and Erez, 2004; Núñez-López et al., 2015; Puterka et al., 2000; Saour, 2005; Spiers et al., 2005; Villanueva and Walgenbach, 2007). Ambrosia beetles are widely reported to be less attracted to white or yellow traps (Dubbel et al., 1985; Entwistle, 1963; Goyer et al., 2004; Mizell and Tedders, 1999; Werle et al., 2014). So in addition to the physical barrier created by kaolin, its bright white color should provide an excellent visual deterrent to ambrosia beetles.

While not necessarily a direct cause of adult mortality, a physical barrier of kaolin will impact insect movement, feeding, and 
oviposition by altering tactile recognition of plant surfaces and attachment of particles to the insect body (Glenn et al., 1999; Larentzaki et al., 2008; Puterka et al., 2000; Unruh et al., 2000). Even when compared with conventional insecticides such as carbaryl, this barrier effect can make kaolin equally proficient at reducing feeding damage by a wide range of insect pests, including Japanese beetle (Popillia japonica Newman) (Mmbaga and Oliver, 2007). Essential oils or pesticides also have been incorporated with applications of kaolin to increase the toxicity of the treatment to insect pests (Marcotegui et al., 2015). For these reasons, we hypothesized that kaolin would provide an effective "push" component in a push-pull ambrosia beetle management strategy.

Prior research conducted by collaborating ambrosia beetle researchers has revealed some attacked trees with indentations excavated just past the bark layer, but not further into the wood, representing galleries that were abandoned by colonizing females before completion. Conversely, a successful Xylosandrus gallery will extend horizontally into the xylem, with gallery diameter and orientation varying depending on species. These abandoned galleries have been observed directly adjacent to completed galleries as well as in more isolated parts of the main stem, but a sufficient explanation has not been made for this phenomenon. By determining a causative factor for abandoned galleries, researchers may be able to recreate conditions that will reduce or prevent ambrosia beetle colonization of ornamental trees, and further investigation is warranted. We present here the first description of abandoned galleries as an assessment of ambrosia beetle attacks on ornamental tree crops.

Because of the incomplete knowledge regarding this economically important pest of ornamental tree production and the need for more diverse and effective control measures, our research objectives are 1) to assess the efficacy of kaolin, both alone and with an insecticide (bifenthrin), for reducing ambrosia beetle attacks over time; and 2) to determine whether there is any correlation between abandoned vs. completed beetle galleries.

\section{Materials and Methods}

Research was conducted at Tennessee State University's Otis Floyd Nursery Research Center in Warren County, TN $\left(35^{\circ} 42^{\prime} 34.81^{\prime \prime} \mathrm{N}, \quad 85^{\circ} 44^{\prime} 27.94^{\prime \prime} \mathrm{W}\right)$, from 2014 to 2015, while in MS there were two test sites. In 2014, a commercial ornamental nursery in Stone County, MS $\left(30^{\circ} 47^{\prime} 59.92^{\prime \prime} \mathrm{N}\right.$, $89^{\circ} 15^{\prime} 21.64^{\prime \prime} \mathrm{W}$ ), was used, but extremely low ambrosia beetle pressure at the nursery led to unusable data and relocation to a different site in 2015: the Thad Cochran Southern Horticultural Laboratory in Pearl River County, MS $\left(30^{\circ} 65^{\prime} 96.84^{\prime \prime} \mathrm{N}, 89^{\circ} 63^{\prime} 50.69^{\prime \prime} \mathrm{W}\right)$.

To stimulate ambrosia beetle attack, containerized $(26.5 \mathrm{~L}$ pots, $\approx 2.5 \mathrm{~cm}$ caliper, $2-3$ years of age) eastern redbud trees (Cercis canadensis L.) were purchased from local nurseries and injected with $75 \mathrm{~mL}$ of $5 \%$ ethanol using an Arborjet Tree I.V. (Arborjet Inc., Woburn, MA) (Ranger et al., 2011; Reding et al., 2013). Following injection, a backpack sprayer (Solo, Newport News, VA) was used to apply 1) bifenthrin (OnyxPro; FMC Corp., Philadelphia, PA), mixed at a rate of $1.25 \mathrm{~mL} \cdot \mathrm{L}^{-1}$; 2) a kaolin crop protectant (Surround WP; Tessenderlo Kerley, Inc., Phoenix, AZ), mixed at $60 \mathrm{~g} \cdot \mathrm{L}^{-1}$; $3)$ a combination of kaolin and bifenthrin $(\mathrm{k}+$ b) mixed at the same rates; and 4) a nontreated control with no sprays. Treatments were twice sprayed onto the main trunk and canopy of the trees until runoff with 10 min delay between applications, yielding roughly 800 $1000 \mathrm{~mL}$ of spray solution per tree. Trees were spaced $20 \mathrm{~m}$ apart in a randomized complete block design along the edge of woodlots at each research site, with blocks also separated by $20 \mathrm{~m}$. The MS site had five replicates in 2015, while the TN site had four replicates in both 2014 and 2015.

Tests began during peak ambrosia beetle flight at each site (early April in MS and early May in TN), with new ambrosia beetle galleries on each tree counted at 1, 4, 6, 8, 11 and 13 DAT. Beetle galleries were circled with a wax pencil to prevent recounting of previous attacks. In addition to counts of completed galleries, counts were made of abandoned galleries, which were indicated by partially excavated holes with no beetle present.

Statistical analysis. Statistical analyses were conducted using SAS 9.4 (SAS Institute Inc., Cary, NC), and based on $\alpha=0.05$. Pearson's correlation analysis was conducted on the number of galleries vs. abandoned galleries on each tree to determine if there was a significant relationship (the CORR procedure). The dependent variable, number of galleries (abandoned + completed) per treatment, was tested separately for each site using generalized linear mixed models with the Poisson distribution and log link function within the GLIMMIX procedure. Mean separation was tested using a Tukey-Kramer pairwise comparison, also within the GLIMMIX procedure. Fixed effects in our model were year, time, treatment, and their second-order interactions. Number of galleries was the response variable, and tree was a random variable within each treatment.

\section{Results}

Correlation analysis revealed a positive trend, though the relationship between the number of completed vs. abandoned galleries was not significant $(r=0.2264 ; P=0.107)$. Because of this nonsignificance, subsequent analysis was conducted on combined initiated gallery counts (abandoned + completed), which could be interpreted as the total number of ambrosia beetle attacks. Even so, it is clear to see that a greater proportion of abandoned galleries were initiated in trees with kaolin or $\mathrm{k}+\mathrm{b}$ treatments (Fig. 1).

Analysis of variance determined a statistically significant model for each of the fixed effects, as well as their interactions (Table 1). Mean separation analysis of TN data showed the number of ambrosia beetle galleries on nontreated control trees to be significantly higher than other treatments, while kaolintreated trees had significantly more galleries than both the bifenthrin- and $\mathrm{k}+\mathrm{b}$-treated trees (Table 2). While $\mathrm{k}+\mathrm{b}$-treated trees had numerically fewer attacks than the bifenthrin-treated trees, the difference was not statistically significant. For the MS data, mean separation analysis showed significantly fewer galleries in $\mathrm{k}+\mathrm{b}$-treated trees as compared with the other three treatments, none of which were significantly different from each other (Table 2).

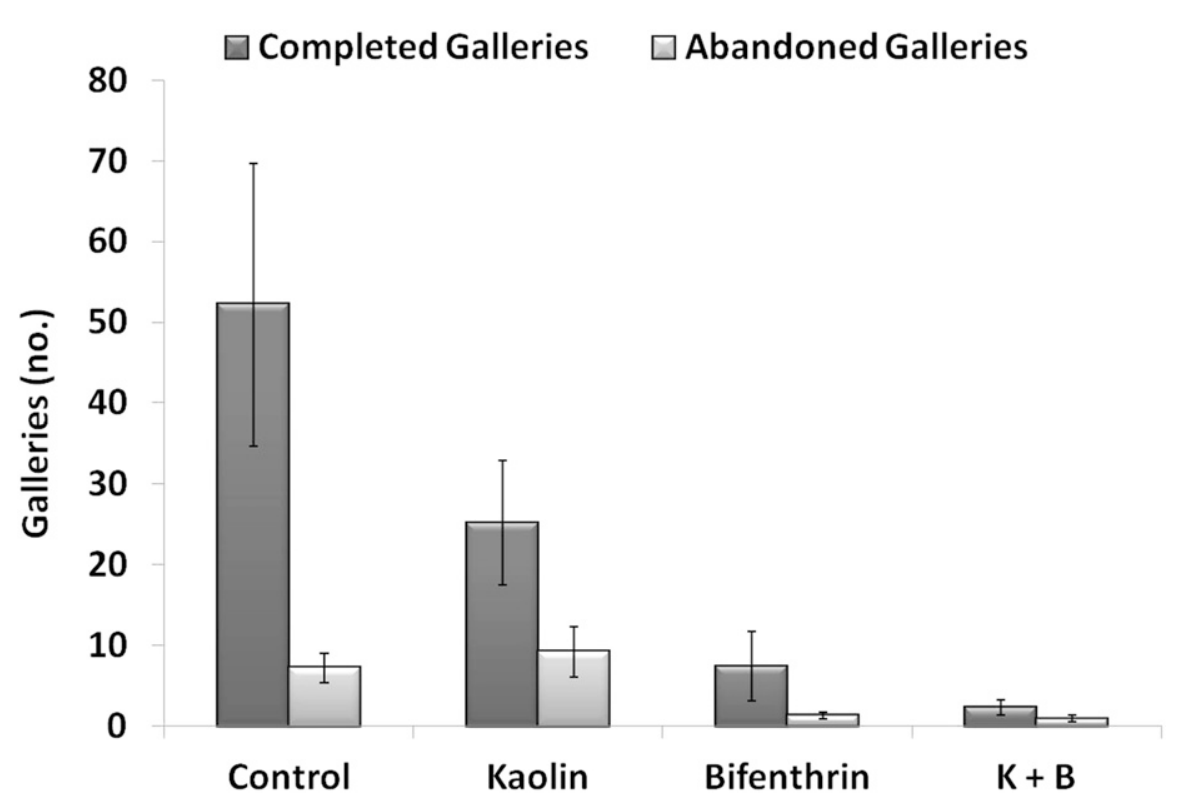

Fig. 1. Mean $( \pm \mathrm{SE})$ number of completed and abandoned ambrosia beetle galleries from each of four tree treatments in Mississippi (2015) and Tennessee (2014-15). 
Table 1. Analysis of variance on total galleries per tree for trees receiving four treatments, with counts of galleries made over six observation dates (1-13 d after treatment) in Tennessee (TN; 2014-15) or five observation dates (1-13 d after treatment) in Mississippi (MS; 2015).

\begin{tabular}{llccrr}
\hline State & Fixed effects & Numerator DF & Denominator DF & $F$ value & $\operatorname{Pr}>F$ \\
\hline TN & Treatment & 3 & 161 & 39.42 & $<0.0001$ \\
& Time & 5 & 161 & 15.34 & $<0.0001$ \\
& Year & 1 & 161 & 5.29 & 0.0228 \\
& Treatment $\times$ time & 15 & 161 & 4.89 & $<0.0001$ \\
& Treatment $\times$ year & 3 & 161 & 9.81 & $<0.0001$ \\
& Treatment & 3 & 76 & 4.96 & 0.0034 \\
MS & Time & 4 & 76 & 9.48 & $<0.0001$ \\
& Treatment $\times$ time & 12 & 76 & 2.5 & 0.008 \\
\hline
\end{tabular}

Fixed effects and their interactions are considered significant at $\alpha=0.05$ level.

Table 2. Tukey-Kramer analysis of least squares means of counts of ambrosia beetle galleries from containerized redbud trees with four treatments in Tennessee (TN; 2014-15) and Mississippi (MS; 2015) $(\alpha=0.05)$.

\begin{tabular}{llc}
\hline State & \multicolumn{1}{c}{ Treatments } & $\begin{array}{c}\text { Estimated } \\
\text { no. of galleries }\end{array}$ \\
\hline TN & Nontreated & $1.64 \mathrm{a}$ \\
& Kaolin & $0.8429 \mathrm{~b}$ \\
& Bifenthrin & $-2.3146 \mathrm{c}$ \\
& Kaolin + bifenthrin & $-2.3809 \mathrm{c}$ \\
MS & Nontreated & $1.0564 \mathrm{a}$ \\
& Kaolin & $0.9264 \mathrm{a}$ \\
& Bifenthrin & $0.6987 \mathrm{a}$ \\
& Kaolin + bifenthrin & $-0.578 \mathrm{~b}$ \\
\hline
\end{tabular}

Least squares means with the same letter are not significantly different.

\section{Discussion}

The results of our correlation analysis lead us to believe that ambrosia beetle gallery abandonment is not simply a density-dependent phenomenon, i.e., greater abandonment on trees with more attacks, but we are still unsure what causes some ambrosia beetles to cease excavation prematurely. No other reports on this potentially important life history trait are known, but one possible explanation is predation of foundress beetles during gallery excavation. Checkered beetles (Coleoptera: Cleridae) are well-known scolytine predators, and are readily collected from ethanol-baited traps (Allison et al., 2013; Werle et al., 2012). Another explanation for gallery abandonment may be a rejection of that region of the tree by the foundress beetle if it is deemed unsatisfactory for brood development. For example, our tree treatments may have disrupted contact or volatile cues for the foundress, thereby increasing the likelihood of gallery abandonment as compared with nontreated control trees. The kaolin treatment also may have served as an irritant to colonizing beetles. Although the relationship between completed and abandoned galleries was not significant, it is still interesting to note the higher proportion of abandoned galleries on kaolin$(26.6 \%)$ and $\mathrm{k}+\mathrm{b}$-treated $(28.6 \%)$ trees as compared with the bifenthrin-treated $(15 \%)$ and nontreated control (12.1\%) trees (Fig. 1). Future tests of ambrosia beetle attacks on trees that include measurements of gallery abandonment will further clarify this phenomenon and may assist in determining more effective treatment options.
A comparison between the two states of the mean completed beetle galleries over time reveals a similar trend in greater efficacy of the bifenthrin treatments over the kaolin, particularly at the earlier observations (Figs. 2 and 3). However, there are also some important differences in results from the two states, including a much larger ambrosia beetle population in $\mathrm{TN}$. There was also a greater efficacy of the kaolin treatment in $\mathrm{TN}$, with significantly fewer galleries excavated on these trees through 4 DAT in comparison with counts from the nontreated control trees. At no time in MS were the kaolin-treatments significantly different from the nontreated control trees, and a potential explanation may be that over the course of the experiment, we observed a diminishing coverage of the kaolin layer on the trees. There was persistent, heavy rain during the whole second week of the test in 2015 (4-8 DAT), and tree bark was so damp that it became difficult to distinguish the tiny entrances to the beetle galleries, with extruded frass tubes often washed away as well. Circling the galleries on the wet bark to prevent recounts was not possible during particularly heavy storms at 8 DAT, so data were not recorded in MS on this date. By 6 DAT in MS, the bifenthrin treatments also seemed to lose some efficacy. While attacks were still numerically lower than with the nontreated control trees, both bifenthrin- and $\mathrm{k}+\mathrm{b}$-treated trees were not significantly different from the kaolin-treated trees at $6 \mathrm{DAT}$, and it is possible that these treatments were also being degraded by the torrential downpours. Prior reports recommend repeating bifenthrin applications in 10 $14 \mathrm{~d}$ intervals during peak beetle flights, but our MS data suggest that this interval may need to be shortened during extended periods of heavy rains (Hudson and Mizell, 1999).

In $\mathrm{TN}$, there was a much more consistent trend of beetle gallery reduction on the bifenthrin- and $\mathrm{k}+\mathrm{b}$-treated trees. By 6 DAT, the kaolin seemed to lose efficacy in comparison with the nontreated control trees, but the bifenthrin- (97\% fewer) and $\mathrm{k}+\mathrm{b}$ (98\% fewer) treated trees had significantly fewer galleries than the nontreated control trees, and continued to protect trees from 1 to 13 DAT. Because we did not observe any significant differences between the bifenthrin and $\mathrm{k}+\mathrm{b}$ treatments, we surmise that the suppression of gallery construction provided by the $\mathrm{k}+\mathrm{b}$ treatment was primarily due to the bifenthrin component.

While kaolin did provide some early control, coverage on kaolin-treated trees was observed to steadily diminish following rain events, while coverage on the $\mathrm{k}+\mathrm{b}$ treated trees appeared to persist longer; it is possible that the additional surfactant present in the bifenthrin product was responsible for this apparent extended coverage. Our observations parallel those from other researchers, who found that kaolin makes a good alternative to conventional chemicals in a variety of crop settings, but its hydrophilic nature makes repeated applications necessary (Glenn et al., 1999; Larentzaki et al., 2008). A technical representative of the kaolin manufacturer did recommend that a layering effect or incorporation of an additional spreader/stickertype adjuvant may be necessary for adequate persistence $(\mathrm{K}$. Volker, personal communication).

When combined with a supplementary surfactant that can prolong persistence on trees, kaolin applications may contribute some deterrent to ambrosia beetle attacks. It is interesting to note that, in both states, the lowest numbers of ambrosia beetle galleries at every observation time from 1 to 13 DAT were made at the $\mathrm{k}+\mathrm{b}$-treated trees. However, further research is needed to determine the degree of additional control, as well as cost-efficacy of repeated applications before loss of coverage is experienced. For example, adding kaolin to an ambrosia beetle management program may afford a rate reduction of bifenthrin, and tests of a variety of adjuvants such as surfactants, spreaders, or stickers may yield an optimal kaolin application technique. But at this point, without these additional data, we cannot recommend kaolin as a "push" component within a push-pull ambrosia beetle IPM strategy.

Aside from reducing ambrosia beetle infestations, kaolin is known to have a wide range of horticultural benefits in crop production. Much research has been directed toward kaolin's reduction of heat stress and increase of leaf carbon assimilation, as well as fruit weight, quality, and yield in a variety of crops (Glenn et al., 1999, 2001, 2002, 2003; Melgarejo et al., 2004; Saour, 2005). Containerized plants in southeastern ornamental nurseries can be subjected to chronic heat stress during summer months, which can lead to water loss, metabolic lesions, decreased photosynthetic and respiration efficiency, loss of membrane integrity, and electrolyte leakage. Due to reflection of infrared radiation, applications of kaolin can significantly reduce tree canopy temperatures and heat stress, which may lead to less induction of ambrosia beetle attacks (Glenn et al., 1999, 2001).

A coating of hydrophobic kaolin can also be as effective as conventional fungicides at obstructing disease inoculum from infecting host tissues (Glenn et al., 1999; Marco and Cohen, 1994; Mmbaga and Oliver, 2007). While the symbiotic fungi associated with many species of ambrosia beetles 


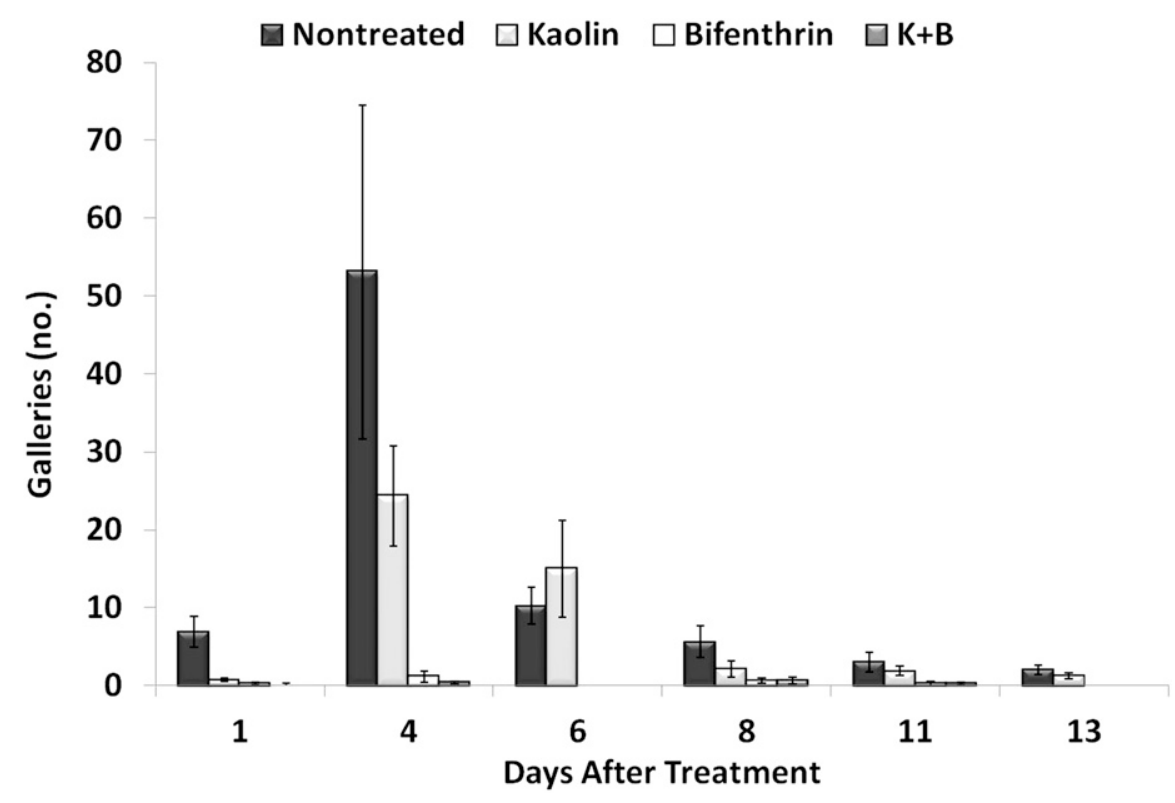

Fig. 2. Mean $( \pm \mathrm{SE})$ number of new ambrosia beetle galleries (abandoned + completed) counted over six observation dates on trees receiving four tree treatments in Tennessee (2014-15). Counts could not be made on one date in 2015 due to persistent heavy rains ( $6 \mathrm{~d}$ after treatment).

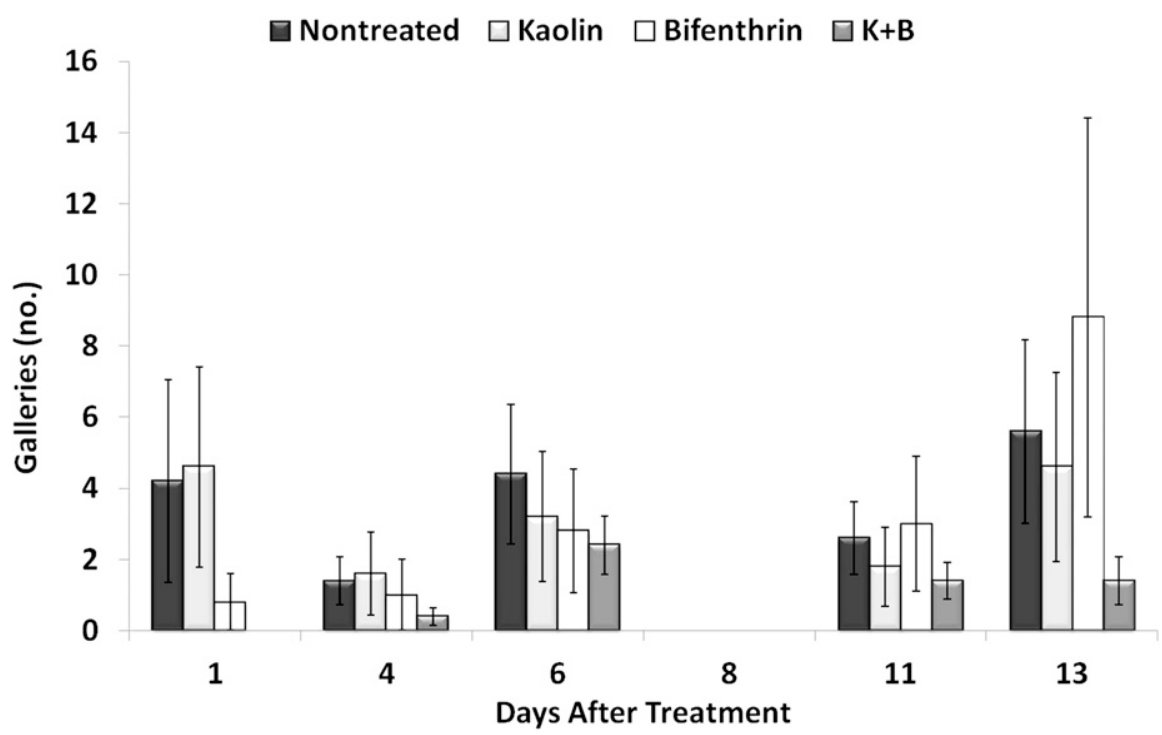

Fig. 3. Mean $( \pm \mathrm{SE})$ number of new ambrosia beetle galleries (abandoned + completed) counted over six observation dates on trees receiving four tree treatments in Mississippi (2015). Counts could not be made on one date due to persistent heavy rains ( $8 \mathrm{~d}$ after treatment).

(Ambrosiella sp.) may not be primary pathogens in host trees, galleries weaken trees and become an easy entry point for more virulent secondary infections, including Fusarium sp. (Anderson and Hoffard, 1978; Dute et al., 2002; Kessler, 1974; Kinuura, 1995; Kuhnholz et al., 2001; Weber and McPherson, 1984). In recent years, researchers have noticed an increase in spring mortality of trees apparently caused by ambrosia beetle attacks and infection by Fusarium sp. but believed it to be more directly related to winter freeze injury (Ranger et al., 2016). Wide temperature fluctuations during winter months lead to loss of tree dormancy and subsequent freeze injury, with damaged bark
2002). Further research on the impact kaolin can make in reducing tree stress and subsequent susceptibility to ambrosia beetle attacks and Fusarium infections is warranted.

\section{Literature Cited}

Allison, J.D., J.L. McKenney, D.R. Miller, and M.L. Gimmel. 2013. Kairomonal response of natural enemies and associates of the southern Ips (Coleoptera: Curculionidae: Scolytinae) to ipsdienol, ipsenol and cis-verbenol. J. Insect Behav. 26:321-335.

Anderson, R.L. and W.H. Hoffard. 1978. Fusarium canker ambrosia beetle complex on tulip poplar in Ohio. Plant Dis. Rpt. 62:751.

Biedermann, P.H.W. and M. Taborsky. 2011 Larval helpers and age polyethism in ambrosia beetles. Proc. Natl. Acad. Sci. USA 108:1706417069.

Burbano, E.G., M.G. Wright, N.E. Gillette, S. Mori, N. Dudley, T. Jones, and M. Kaufmann. 2012. Efficacy of traps, lures, and repellents for Xylosandrus compactus (Coleoptera: Curculionidae) and other ambrosia beetles on Coffea arabica plantations and Acacia koa nurseries in Hawaii. Environ. Entomol. 41:133-140.

Campbell, P.J. 2013. Declining European bee health: Banning the neonicotinoids is not the answer. Outlooks Pest Mgt. 24:52-57.

Choi, W.I. 2011. Influence of global warming on forest coleopteran communities with special reference to ambrosia beetles. J. Asia Pac. Entomol. 14:227-231.

Cook, S.M., Z.R. Khan, and J.A. Pickett. 2007. The use of push-pull strategies in integrated pest management. Annu. Rev. Entomol. 52:375400.

Dubbel, V., K. Kerck, M. Sohrt, and S. Mangold. 1985. Influence of trap color on the efficiency of bark beetle pheromone traps. J. Appl. Entomol. 99:59-64.

Dute, R.R., M.E. Miller, M.A. Davis, F.M. Woods, and K.S. McLean. 2002. Effects of ambrosia beetle attack on Cercis canadensis. IAWA J. 23:143-160.

Entwistle, P.F. 1963. Some evidence for a colour sensitive phase in the flight period of Scolytidae and Platypodidae. Entomol. Exp. Appl. 6:143-148.

Fraedrich, S.W., T.C. Harrington, R.J. Rabaglia, M.D. Ulyshen, A.E. Mayfield, J.L. Hanula, J.M. Eickwort, and D.R. Miller. 2008. A fungal symbiont of the redbay ambrosia beetle causes a lethal wilt in redbay and other Lauraceae in the southeastern United States. Plant Dis. 92: 215-224.

Frank, S.D. and C.S. Sadoff. 2011. Reducing insecticide volume and non-target effects of ambrosia beetle management in nurseries. $\mathrm{J}$. Econ. Entomol. 104:1960-1968.

Fulcher, A., W.E. Klingeman, J.H. Chong, A. LeBude, G.R. Armel, M. Chappell, S. Frank, F. Hale, J. Neal, S. White, J. Williams-Woodward, K. Ivors, C. Adkins, A. Senesac, and A. Windham. 2012. Stakeholder vision of future direction and strategies for southeastern U.S. Nursery Pest Research and Extension Programming. J. Integr. Pest Mgt. 3:1-8.

Glenn, D.M., A. Erez, G.J. Puterka, and P. Gundrum. 2003. Particle films affect carbon assimilation and yield in 'Empire' apple. J. Amer. Hort. Sci. 128:356-362

Glenn, D.M., E. Prado, A. Erez, J. Mcferson, and G.J. Puterka. 2002. A reflective, processedkaolin particle film affects fruit temperature, radiation reflection and solar injury in apple. $\mathrm{J}$. Amer. Hort. Sci. 127:188-193. 
Glenn, D.M., G.J. Puterka, S.R. Drake, T.R. Unruh, A.L. Knight, P. Baherle, and E. Prado. 2001. Particle film application influences apple leaf physiology, fruit yield and fruit quality. J. Amer. Hort. Sci. 126:175-181.

Glenn, D.M., G.J. Puterka, T. Vanderzwet, R.E. Byers, and C. Feldhake. 1999. Hydrophobic particle films: A new paradigm for suppression of arthropod pests and plant diseases. J. Econ. Entomol. 92:759-771.

Goyer, R.A., G.J. Lenhard, and B.L. Strom. 2004. The influence of silhouette, color and orientation on arrival and emergence of Ips pine engravers and their predators in loblolly pine. For. Ecol. Mgt. 191:147-155.

Hudson, W. and R.F. Mizell. 1999. Management of an Asian ambrosia beetle, Xylosandrus crassiusculus, in nurseries. Proc. Southern Nursery Growers Assoc. 44:198-201.

Kamata, N., K. Esaki, K. Kato, Y. Igeta, and K. Wada. 2002. Potential impact of global warming on deciduous oak dieback caused by ambrosia fungus Raffaelea $\mathrm{sp}$. carried by ambrosia beetle Platypus quercivorus (Coleoptera: Platypodidae) in Japan. Bull. Entomol. Res. 92: 119-126.

Kessler, Jr., K. 1974. An apparent symbiosis between Fusarium fungi and ambrosia beetles causes canker on black walnut stems. Plant Dis. Rpt. 58:1044-1047.

Kinuura, H. 1995. Symbiotic fungi associated with ambrosia beetles. Jpn. Agr. Res. Q. 29:57.

Kolarik, M., E. Freeland, C. Utley, and N. Tisserat. 2011. Geosmithia morbida sp. nov., a new phytopathogenic species living in symbiosis with the walnut twig beetle (Pityophthorus juglandis) in USA. Mycologia 103:325-332.

Kuhnholz, S., J.H. Borden, and A. Uzonovic. 2001. Secondary ambrosia beetles in apparently healthy trees: Adaptations, potential causes and suggested research. Integr. Pest Mgt. Rev. 6:209-219.

Larentzaki, E., A.M. Shelton, and J. Plate. 2008. Effect of kaolin particle film on Thrips tabaci (Thysanoptera: Thripidae) oviposition, feeding and development on onions: A lab and field study case. Crop Prot. 27:727-734.

Marco, S.O.Z. and R. Cohen. 1994. Suppression of powdery mildew in squash by applications of whitewash, clay and antitranspirant materials. Phytoparasitica 22:19-29.

Marcotegui, A., I. Sánchez-Ramos, S. Pascual, C. E. Fernández, G. Cobos, I. Armendáriz, A. Cobo, and M. González-Núñez. 2015. Kaolin and potassium soap with thyme essential oil to control Monosteira unicostata and other phytophagous arthropods of almond trees in organic orchards. J. Pest Sci. 88:753-765.

Mazor, M. and A. Erez. 2004. Processed kaolin protects fruits from Mediterranean fruit fly infestations. Crop Prot. 23:47-51.

Melgarejo, P., J.J. Martínez, F. Hernández, R. Martínez-Font, P. Barrows, and A. Erez. 2004. Kaolin treatments to reduce pomegranate sunburn. Sci. Hort. 100:349-353.

Mizell, R., S.K. Braman, B. Sparks, and W. Hudson. 1994. Outbreak of the Asian ambrosia beetle Xylosandrus crassiusculus (Motschulsky) is cause for concern. Proc. Southern Nursery Growers Assoc. 39:191-193.

Mizell, R.F. and W.L. Tedders. 1999. Evaluation of trap type and color for monitoring Hylobius pales and Pachylobius picivorus in Florida. Fla. Entomol. 82:615-624.

Mmbaga, M.T. and J.B. Oliver. 2007. Effect of biopesticides on foliar diseases and Japanese beetle (Popillia japonica) adults in roses (Rosa spp.), oakleaf hydrangea (Hydrangea quercifolia) and crape myrtle (Lagerstroemia indica). Arboric. Urban For. 33:210-219.

Núñez-López, D.C., A. Ramírez-Godoy, and H. Restrepo-Díaz. 2015. Impact of kaolin particle film and synthetic insecticide applications on whitefly populations Trialeurodes vaporarium (Hemiptera: Aleyrodidae) and physiological attributes in bean (Phaseolus vulgaris) crop. HortScience 51:1503-1508.

Oliver, J.B. and C.M. Mannion. 2001. Ambrosia beetle (Coleoptera: Scolytidae) species attacking chestnut and captured in ethanol-baited traps in middle Tennessee. Environ. Entomol. 30:909-918.

Pimentel, D., H. Acquay, M. Biltonen, P. Rice, M. Silva, J. Nelson, V. Lipner, S. Giordano, A. Horowitz, and M. D’Amore. 1992. Environmental and economic costs of pesticide use. BioSci. 42:750-760.

Puterka, G.J., D.M. Glenn, D.G. Sekutowski, T.R. Unruh, and S.K. Jones. 2000. Progress toward liquid formulations of particle films for insect and disease control in pear. Environ. Entomol. 29:329-339.

Ranger, C.M., M.E. Reding, J.B. Oliver, P.B. Schultz, J.J. Moyseenko, and N. Youssef. 2011. Comparative efficacy of plant-derived essential oils for managing ambrosia beetles (Coleoptera: Curculionidae: Scolytinae) and their corresponding mass spectral characterization. J. Econ. Entomol. 104:1665-1674.

Ranger, C.M., M.E. Reding, A.B. Persad, and D.A. Herms. 2010. Ability of stress-related volatiles to attract and induce attacks by Xylosandrus germanus and other ambrosia beetles. Agr. For. Entomol. 12:177-185.

Ranger, C.M., M.E. Reding, P.B. Schultz, and J.B. Oliver. 2012. Ambrosia beetle (Coleoptera: Curculionidae) responses to volatile emissions associated with ethanol-injected Magnolia virginiana. Environ. Entomol. 41:636-647.

Ranger, C.M., M.E. Reding, P. Schultz, J. Oliver, S. Frank, K. Addesso, J.H. Chong, B.J. Sampson, C.T. Werle, S. Gill, and C. Krause. 2016. Biology, ecology and management of Xylosandrus spp. ambrosia beetles (Coleoptera: Curculionidae: Scolytinae) in ornamental tree nurseries. J. Integr. Pest Mgt. 7:1-23.

Ranger, C.M., P.C. Tobin, and M.E. Reding. 2015. Ubiquitous volatile compound facilitates efficient host location by a non-invasive ambrosia beetle. Biol. Invasions 17:675-686.

Ranger, C.M., P.C. Tobin, M.E. Reding, A.M. Bray, J.B. Oliver, P.B. Schultz, S.D. Frank, and A.B. Persad. 2013. Interruption of the semiochemicalbased attraction of ambrosia beetles to ethanolbaited traps and ethanol-injected trap trees by verbenone. Environ. Entomol. 42:539-547.
Reding, M.E., J.B. Oliver, P.B. Schultz, C.M. Ranger, and N.N. Youssef. 2013. Ethanol injection of ornamental trees facilitates testing insecticide efficacy against ambrosia beetles (Coleoptera: Curculionidae: Scolytinae). J. Econ. Entomol. 106:289-298.

Reding, M.E., C.M. Ranger, B.J. Sampson, C.T. Werle, J.B. Oliver, and P.B. Schultz. 2015. Movement of Xylosandrus germanus (Coleoptera: Curculionidae) in ornamental nurseries and surrounding habitats. J. Econ. Entomol. 108:1947-1953.

Reding, M.E., P.B. Schultz, C.M. Ranger, and J.B. Oliver. 2011. Optimizing ethanol-baited traps for monitoring damaging ambrosia beetles (Coleoptera: Curculionidae: Scolytinae) in ornamental nurseries. J. Econ. Entomol. 104:20172024.

Relf, P.D. and B. Appleton. 2015. Managing winter injury to trees and shrubs. Virginia Coop. Ext. Publ. 426-500. 12 Jan. 2016. <https://pubs.ext.vt. edu/426/426-500/426-500_pdf.pdf $>$.

Saour, G. 2005. Efficacy of kaolin particle film and selected synthetic insecticides against pistachio psyllid Agonoscena targionii (Homoptera: Psyllidae) infestation. Crop Prot. 24:711-717.

Spiers, J.D., F.B. Matta, D.A. Marshall, and B.J. Sampson. 2005. Effects of kaolin clay application on flower bud development, fruit quality and yield, and flower thrips [Frankliniella spp. (Thysanoptera: Thripidae)] populations of blueberry plants. Small Fruits Rev. 4:73-84.

Unruh, T.R., A.L. Knight, J. Upton, D.M. Glenn, and G.J. Puterka. 2000. Particle films for suppression of the codling moth (Lepidoptera: Tortricidae) in apple and pear orchards. J. Econ. Entomol. 93:737-743.

VanDerLaan, N.R. and M.D. Ginzel. 2013. The capacity of conophthorin to enhance the attraction of two Xylosandrus species (Coleoptera: Curculionidae: Scolytinae) to ethanol and the efficacy of verbenone as a deterrent. Agr. For. Entomol. 15:391-397.

Villanueva, R.T. and J.F. Walgenbach. 2007. Phenology, management and effects of Surround on behavior of the apple maggot (Diptera: Tephritidae) in North Carolina. Crop Prot. 26:1404-1411.

Weber, B.C. and J.E. McPherson. 1984. The ambrosia fungus of Xylosandrus germanus (Coleoptera: Scolytidae). Can. Entomol. 116: 281-283.

Werle, C.T., A.M. Bray, J.B. Oliver, E.K. Blythe, and B.J. Sampson. 2014. Ambrosia beetle (Coleoptera: Curculionidae: Scolytinae) captures using colored traps in southeast Tennessee and south Mississippi. J. Entomol. Sci. 49:373-382.

Werle, C.T., J.H. Chong, B.J. Sampson, M.E. Reding, and J.J. Adamczyk. 2015. Seasonal and spatial dispersal patterns of select ambrosia beetles (Coleoptera: Curculionidae) from forest habitats into production nurseries. Fla. Entomol. 98:884-891.

Werle, C.T., B.J. Sampson, and J.B. Oliver. 2012. Diversity, abundance and seasonality of ambrosia beetles (Coleoptera: Curculionidae) in southern Mississippi. Midsouth Entomol. 5:1-5. 